\title{
Effect of Human Resources, Leadership Style, The Use of Information Technology and Internal Control on the Quality of Financial Statements
}

\author{
Trisdina Mardinan \\ Ministry of Works and Public Housing \\ Muhammad Dahlan \\ Department of Accounting - Faculty of Economics and Business \\ Universitas Padjadjaran \\ Furry K Fitriyah \\ Department of Accounting - Faculty of Economics and Business \\ Universitas Padjadjaran
}

\begin{abstract}
This study aims to examine whether there is a significant influence of variable human resources competency, leadership, utilization of information technology, internal control of the quality of financial statements either partially or simultaneously. The population in this research is all work units (SATKER) within the Directorate General of Construction Materials for 15 units of work with 45 respondents consisting of financial assistant of the work unit, the Accounting officer of Accrual Based Institution (SAIBA) and State Owned Officer (BMN). The primary used the data Obtained from respondents through questionnaires, for testing the data tested the validity, reliability test, and hypothesis testing. The Data then in the analysis with the analysis method used is multiple linear regression. The results showed that the competence of human resources, leadership style, technology utilization, and internal control Affect the quality of financial statements either partially or simultaneously.
\end{abstract}

Keywords: Human resources; Leadership; Information technology; Quality of financial statements

\section{Introduction}

The development of public sector accounting, particularly in Indonesia proliferated in the presence of the Reform Era in the implementation of government policy, public expectations towards the improvement of transparency and accountability in financial management countries as part of the reform of government management so high (Mardiasmo, 2005). It is in line with Anwar Nasution (2009), which confirms that the improvement of transparency and accountability of fiscal or financial state is an important part of enforcement of good governance. The purpose of the financial reform of the state is to realize good governance in the administration and management of state finances. Explanation of the Law No. 17 of 2003 on state finances states that to support good governance, public finance management should be organized in a professional, open and accountable. Furthermore, in Law No. 1 of 2004 on State 
treasury also confirmed that for realized transparency and accountability in the management of state finances, the government must make the financial responsibility report prepared under Government Accounting Standards (SAP). Government Regulation (PP) number 71 of 2010 concerning Government Accounting Standards (SAP) which in this regulation states that the financial statements can be said to have a good quality if it meets the qualitative characteristics of financial statements covering the four elements of relevant, reliable, comparable, and can be understood. Huang et al. (1999) state that the usefulness of the information and financial statements can be viewed from the side its role in decision making and ease to understand the consumer.

In this case, the Ministry PUPR prepare and submit accountability reports each year and get opinions from BPK. Opinion Ministry PUPR from 2011 till 2015 had been developed. In 2011 gets WDP, the year 2012 increased WTP-DPP, in 2013 the Ministry of PUPR won WTP opinion. Although it had won WTP opinion, this is not apart from problems related to financial management findings. Then in 2014 got a WTP opinion-DPP, and in 2015 fell back to WDP.

Best Opinion issued by the CPC on LKPP audit was the unqualified opinion (WTP). In the State Financial Inspection Standards (SPKN), WTP opinion will be given to LKPP who have presented and disclose financial statements fairly, in all material respects. Representation of reasonableness outlined in the form of opinion considering the suitability criteria of the financial statements with government accounting standards (SAP), the adequacy of disclosure, compliance with laws and regulations, and the effectiveness of internal controls (max 2009).
From the findings of the BPK on the financial statements of the Ministry PUPR one being the findings exist in DG Construction, including differences in proof of payment of the package full-day meeting of the executive activities of the documented accountability is not in accordance with actual conditions, liability cost of surveys by consultants indicated fictitious, accountability workshop by consultant fees indicated fictitious, weak and not optimal to exercise supervision and control of the leadership and commitment of officials (KDP) is negligent in implementing and approving payments. Those problems are a combination of non-compliance with government accounting standards, weakness internal control system, and non-compliance with statutory provisions findings on the financial statements given, indicating their weaknesses and shortcomings on several factors that affect the quality of financial reporting. These factors include the competence of human resources, leadership, use of information technology and internal controls.

The former because of the limited competence of human resources (HR). The financial statements can be qualified if the competence of human resources knowledge discount, ability (skills) and attitude (attitude) that the process of financial management and financial reporting going well. The second factor affecting the quality of the financial statements is the style of leadership. Leaders are required to give a example, can be motivating, as solving the problem (breaker / finisher problems) and as control / checker on the implementation of the responsibilities exercised by employees who become subordinate, or in other words, a leader must have the management capabilities of organizations in both labor management aspects as well as aspects of human resource management. Here, the role and the burden to be borne by someone 
official or head of that if it is not entrusted then what is the vision and mission of the institution even government programs will not be achieved as expected.

The third factor is the utilization of information technology, the problems that exist in the DG Construction are each standalone applications and has a separate database, but the interaction of both input and output of data related to each other from one application to another application. It often leads to various problems in the field, such as not fitting the output result one application with another application, imperfect process of migration of data between applications, to the difficulty in verifying the data and documents due to the same source noted repeatedly in different applications.

The final factor is the problem in terms of internal control. The results of tests carried out BPK found that the presence of the Work Package Workshop within the framework of the proven Control Management Training paid not according to the actual conditions (Indications fictitious) and the payment exceeds the standard General Cost (SBU) FY 2015 based on a document of accountability. The discovery of evidence of liability in the form of air tickets and airline boarding pass on seven surveyors (14 roundtrip flights) are not found in the database of airline passenger manifest and besides their accommodation costs and per diem for seven surveyors. From the evidence of the payment of fictitious indicated that could harm the state. It shows that it is still less than optimal monitoring and control on official travel and work packages by leaders and officials of the commitment maker.

The purpose of this study was to determine and analyze how much influence the competence of human resources, leadership, use of information technology, and internal controls partially or simultaneously to the quality of the financial statements.

\section{Literature And Hypotheses Development}

\section{Decision Usefulness Theory}

Belkaoui (2001) stated that Chambers was the first to use the paradigm of usefulness decision."Therefore, a natural result of the assumption of rational management is that there should be a system that provides an information; Unlike systems that required both a basis for making decisions or base to regain the consequences of decisions. System formally presenting information will adjust to two general proposition. The first is the condition of any scientific discourse, and it shall logically consistent system; there are no rules or processes that can conflict with any rule or other processes. Both appear on the user's accounting reports as a basis for decision making on the consequences of the practice, the information generated by each system should be relevant to various forms of decision-making that are expected to be used "(Chambers, 1984 in Belkoui, 2001)

Statements of Financial Accounting Concept (SFAC) ᄀ No. 2 on Qualitative Characteristics of Accounting Information describes the hierarchy of accounting quality in terms of the quality of primary and secondary qualities. The primary quality of information that is useful in making economic decisions are relevant value (relevance) and reliability (reliability).

Financial Accounting Standards Board (FASB) states that the relevant value and reliability are the two main qualities that make accounting information useful in decision making. Relevant value are classified as capacity information to make a difference in decision-making by users. Reliability is defined as the quality of a guarantee that the information was rationally free from error and bias, and represents what 
will be described. To be relevant, information must be logical concerning a decision.

\section{Human Resources competencies}

There are different theories as to the Human Resources (HR) to confirm the role and contribution of HR to the achievement of organizational goals. In the context of governance, HR acts as a change agent who was instrumental in the government's financial reporting activities, namely as one of the activities that become an integral part of the effort to achieve organizational goals. One of the concepts of human resource can be seen in the concept of scientific management. Taylor (1911), Gudono (2014a: 37) states there are five (5) main ideas of scientific management, and 2 (two) of them related to human resource factors, namely the selection of the right people to do the work and training of employees to do the job efficiently,

Furthermore, Wiley (2002) tried to establish a definition, including indicators of human resources in an organization. Wiley also defines human resources as well as the main pillar wheel drive organizational challenges of realizing the vision and mission and objectives of the organization. (Azhar,2007). In the context of this study, human resource competency is the ability of the compilers of the financial statements of each entity reporting the scope of the government in this case the ministry in carrying out their duties according to the educational background, knowledge and expertise, as well as training programs in accounting and financial reporting that have followed. HR competencies in this study were measured using three indicators, namely: (1) educational background; (2) knowledge and expertise; and training; (3) The division of tasks; and (4) training

\section{Leadership Style}

Leadership, a person's behavior to influence others to achieve a goal in a group or organization so that one can follow the will of the leader. According Yukl (2010: 8) definition of leadership is the process of influencing others to understand and agree with what needs to be done and how the task was done effectively, as well as the process to facilitate individual and collective efforts to achieve common goals while Hughes et al. (1996) stated that leadership as a process of influencing an organized group to achieve group goals.

Yukl (2007: 65) explains that a study found three types of leadership behavior can be distinguished between effective managers and managers are not effective. Three types of leadership behavior in question is a taskoriented behavior, relationship-oriented behavior, and participative leadership, every kind of behavior Yulk described as follows: 1. Task-oriented behavior. Effective managers do not use the time and the attempt is to do the same job as beneath. Conversely, the more effective managers concentrate on functions such as task-oriented plan and organize work, coordinate the technical assistance needed. 2. Relationship-oriented behavior. For effective managers, taskoriented behavior does not occur at the expense of attention to the relationship between human beings. Effective managers more attentive, supportive, and help the subordinates. 3. Oriented changes. This type of behavior, especially pay attention to the improvement of strategic decisions; adaptation to environmental change; increase flexibility and innovation; make significant changes in the process; products and services, and get a commitment to change.

\section{Utilization of Information Technology}

Wilkinson et al. (2000) argue that the use of information technology includes the 
(a) data processing, information processing, management systems, and work processes electronically; and (b) the use of advanced information technologies so that public services can be accessed easily and inexpensively by the community. Statement Wilkinson et al. (2000), confirms that the change became an essential point in the use of information technology is an improvement in terms of 1) processing of transactions and other data faster, 2) Accuracy in the calculation and comparison is more significant, 3) The cost of processing each transaction is lower 4) Preparation of reports and other output faster, 5) the data storage is more compact with higher accessibility when needed, 6) data entry options and the provision of a more extensive output, 7) Productivity is higher for employees and managers.

By adopting Wilkinson et al (2000), further developed indicators of utilization of information technology in this study include: (1) Software (software) applications; (2) the process of computerized accounting; (3) software (software) in accordance with laws and regulations; (4) accounting and managerial integrated (5) maintenance of equipment; (6) repair equipment damaged and (7) are antiviral.

\section{Internal Control}

Government Regulation 60 of 2008 states that the internal control system of government is a process that is integral to the actions and activities that are carried out continuously by the management and all employees to provide reasonable assurance for the achievement of organizational goals through effective and efficient, the reliability of financial reporting, state asset security, and compliance with laws and regulations thoroughly organized in the neighborhood of the central government and local governments. The local government referred to in this regulation includes the district or city government, and the provincial government's internal control system aims to provide reasonable assurance for the achievement of effectiveness and efficiency in achieving the purpose of the state government, the reliability of financial reporting, security of state assets, and compliance with laws invitation. SPIP forming elements (Government Internal Control System), among others: 1) Control Environment, 2) Risk Assessment, 3) Control Activities, 4) Information and Communication, 5) Monitoring Internal Control

\section{Quality of Financial Statements}

Government Regulation No. 71 the Year 2010 on Government accounting standards describes the qualitative characteristics of financial statements is normative measures that need to be realized in the accounting information so that it can fulfill its purpose. The following four characteristics is a normative precondition necessary for the government's financial statements to meet the desired quality:

1. Relevant

$\checkmark$ Having the benefit of feedback (feedback value), the information allows users to define their expectations correcting tool in the past.

$\checkmark$ Has the benefit of predictive (predictive value), the information can help users to predict the future based on the results of past and present events.

$\checkmark$ Timely, timely information is presented so it can be influential and useful in decision making.

$\checkmark$ In addition, the government's financial accounting information is presented as completely as possible which includes all the accounting information which may affect decision-making.). 
2. Reliably

$\checkmark$ Presentation honest, truthful information illustrates the transactions and other events should be presented or could reasonably be expected to be presented.

$\checkmark$ Verifiable (verifiability), the information presented in the financial statements can be tested, and if the test is done more than once by different parties, the results still indicate that not much different conclusion.

$\checkmark$ Neutrality, information directed at the general needs and not in favor of a particular party needs.

3. Can be compared to information contained in the financial statements would be more useful if it can be compared to the prior year financial statements or other reporting entity's financial statements in general.

4. It is understandable information presented in the financial statements can be understood by the user and is expressed in the form and terms that are adjusted to limit the users understanding.

\section{Hypothesis Development}

\section{Effect of human resources competencies to the quality of financial reporting}

The preparation Quality of financial statements requires human resources who control the Government Accounting. human resources are the key factor in creating quality financial statements for preparing the financial statements are those that master the Government Accounting Standards. No matter how good the Government Accounting Standards, without the support of Human Resources that are reliable, the quality of financial statements is difficult to achieve.

Based on the research framework and empirical evidence obtained from previous studies reinforce the notion that human resource competence factor positive effect on the quality of financial reporting. So it can be hypothesized as follows:

\section{H1: Human Resources Competency positive} effect on the quality of financial reporting.

\section{Effect of Leadership Style on the Quality financial statements}

The leader is planners, organizers, leaders, and supervisors in organizations are doing tasks (Luthans, 2006:22). Leaders committed to implementing the task, especially in financial management, also determine how good the quality of the resulting financial statements. According to Luthans (2006: 249) is an attitude that reflects the commitment of loyalty to the organization and ongoing process where members of the organization expressed concern for the organization and success and sustainable progress.

Based on the research framework and empirical evidence obtained from previous studies reinforce the notion that leadership affects the quality of the financial statements, so it can be hypothesized as follows:

H2: Leadership Style positive effect on the quality of the financial statements

\section{Effect of Utilization of Information Technology on the quality of the financial statements}

Information technology (IT) is one of the integral parts of the technology. development information technology is very fast and is used widely in various fields, including in the area of government 
accounting and financial reporting. Information technology much helps the system adopted by the government entities, and Accounting Information Systems (AIS) are computerized to encourage the development of government performance.

Based on the description above, this study is intended to examine the relationship between the competence of human resources with the quality of financial reporting information. The hypothesis can be drawn as follows:

\section{H3: Information Technology Utilization} positive effect on the quality of the financial statements

\section{Effect of Internal Control of the quality of} financial reporting

\section{Internal control on government designed based on the Government Regulation No. 60 of 2008 on. Internal control system (SPI) has a function to provide reasonable assurance for the achievement of effectiveness and efficiency in the accounting process, especially in creating reliability}

financial statements. So that the implementation of the internal control system capable of improving reliability, the objectivity of information and prevent inconsistencies and facilitate the process of auditing the financial statements. As the foundation for the entire process of securing and managing state assets, any government agency shall create and maintain an environment in organizations that encourage behavior (behavior) is positive and healthy management. The main is to encourage the availability of the entire state financial managers who have consciousness (awareness) that strongly about the importance of the enforcement of the internal control system.

Based on the description above, this study is intended to examine the relationship between the ability or the capability of human resources with the quality of financial reporting information. The hypothesis can be drawn as follows:

H4: Internal controls positive effect on the quality of financial reporting.

Figure 1. Conceptual Framework

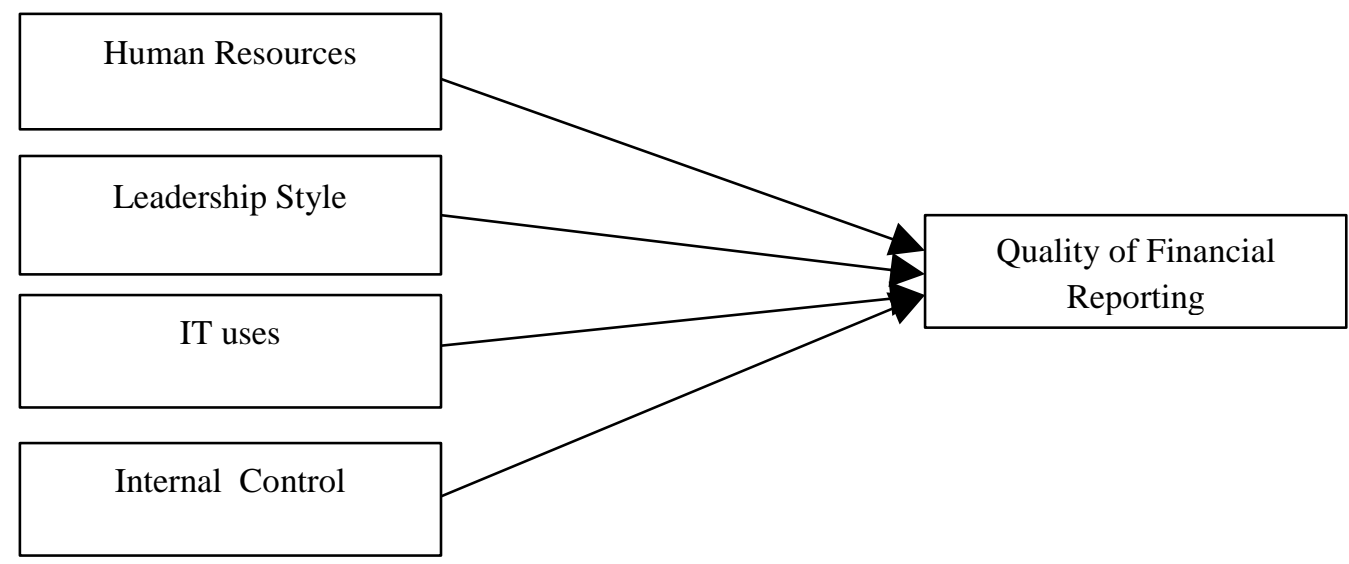




\section{Methodology}

The method used is descriptive method survey explanatory. The population in this study amounted to 15 (fifteen) working unit all the Directorate General of Public Works and Construction Ministry of Housing. The data collection is done directly by using a questionnaire containing 78 questions and interviews as the reinforcement of the results of quantitative research. To determine the relationship simultaneously / synchronously between independent variables on the dependent variable multiple linear regression analysis. Multiple linear regression equation used in this study are:

$$
\mathrm{Y}=\mathrm{a}+\mathrm{b}_{1} \mathrm{X}_{1}+\mathrm{b}_{2} \mathrm{X}_{2}+\mathrm{b}_{3} \mathrm{X}_{3}+\mathrm{b}_{3} \mathrm{X}_{4}+e
$$

$\mathrm{Y}=$ Quality of Financial Statements

$\mathrm{X}_{1}=$ Competence Human Resources

$\mathrm{X} 2$ = Leadership Style

X3 = Utilization of Information Technology

$\mathrm{X} 4=$ Internal Control

$\mathrm{a}=$ Numbers constants

$\mathrm{b}=$ regression coefficient

$\mathrm{e}=$ error

\section{Results and Discussion}

The results of testing the hypothesis by using SPSS can be seen in the following table:

Table 1. Results of hypothesis testing

\begin{tabular}{|c|c|c|c|c|c|c|c|}
\hline \multirow[t]{2}{*}{ Model } & \multicolumn{2}{|c|}{$\begin{array}{l}\text { unstandardized } \\
\text { coefficient }\end{array}$} & \multirow{2}{*}{$\begin{array}{c}\begin{array}{c}\text { Standardize } \\
\mathrm{d}\end{array} \\
\text { coefficients }\end{array}$} & \multirow[t]{2}{*}{$\mathrm{t}$} & \multirow[t]{2}{*}{ Sig. } & \multicolumn{2}{|c|}{ Collinearity Statistics } \\
\hline & B & Std.Error & & & & Tolerance & VIF \\
\hline (Constan) & -10.698 & 3.533 & & -3.028 & .004 & & \\
\hline $\mathrm{X} 1$ & .310 & .117 & .178 & 2.642 & .012 & .435 & 2.297 \\
\hline $\mathrm{X} 2$ & .255 & .109 & .137 & 2.345 & .024 & .573 & 1.744 \\
\hline $\mathrm{X} 3$ & .582 & .065 & .613 & 8.922 & .000 & .416 & 2.403 \\
\hline $\mathrm{X} 4$ & .356 & .049 & .402 & 7.299 & .000 & .647 & 1.546 \\
\hline
\end{tabular}

Based on table 4.1, can be obtained by multiple linear equation as follows:

$\mathrm{Y}=-10.698+0.310 \mathrm{X} 1+0.255 \mathrm{X} 2+0.582$ $+0.356 \mathrm{X} 3 \mathrm{X} 4+\varepsilon$

From these equations are known constants of -10.698 means that if a fourth variable, the independent variable is zero (0) and there is no change, then the quality of financial statements will be worth -10.134 on a scale unit Likert.
Effect of HR Competency, Leadership Style, Utilization of Information Technology, and Internal Control of the Quality of Financial Reports.

Based on the results of the first hypothesis testing showed the competence of human resources, leadership style, the use of IT and internal control together affect the quality of the financial statements, have been proven through hypothesis testing. From the research data obtained calculated $\mathrm{F}$ value of 
117.178 with $\mathrm{p}$-value ( $\operatorname{sig}$ ) of 0.000 . With $\alpha=$ 0.05 and degrees of freedom $\mathrm{v} 1=4$, and $\mathrm{v} 2=$ $40(n-(k+1))$, the importance of the $F$ tables 2.606. Due to F count $>$ F table (117.178> 2,606), H0 is rejected, it means independent variables simultaneously affect the quality of financial reporting.

The results showed a correlation coefficient (R) of 0,960 that the degree of relationship (correlation) between the independent variable on the dependent variable in the category of the relationship is very strong, which means there a relationship between independent variables (HR competency, leadership style, the use of IT and internal control) with the direction of a positive relationship. Any increase in one of the independent variables will lead to rising also in other independent variables.

The R2 value obtained from this study is $92.1 \%$. It shows that simultaneously the three independent variables (HR competency, leadership style, the use of IT, and internal control) contributed (effect) of $92.1 \%$ to the quality of financial reporting while the remaining $7.1 \%$ is influenced by other factors beyond the three independent variables.

\section{Human Resources Competency influence on the Quality of Financial Reports}

Among the two dimensions in the competence of human resources, training dimension is given a score which is the lowest compared with the dimensions of choosing the right people for whose benefit is the category in the category of "good enough" with an average score of 2.86 with a percentage $57.3 \%$. Opportunities for training are significant in developing the human resource competencies to the civil authorities of the country.

In this training dimension of the lowest value obtained at point statement to 11 that Agencies respondents independently frequent technical guidance or training in the field of accounting and financial reporting. This shows that there are employees who feel never had a chance in training ever undertaken by the institution. So that the employee cannot development competence in the field of finance, employees who do not have competence in the financial sector would not be able to prepare financial statements quality.

Based on the results of the first hypothesis testing showed that HR competencies and significant positive effect on the quality of financial reporting. T-count variable HR competencies of 2.642 greater than $2.021 \mathrm{t}$-table or when seen from the significant value is far below the $5 \%$ error rate of 0.012 produces Ho rejected and $\mathrm{Ha}$ accepted means HR competency significantly influence the quality of financial reporting. In addition, HR competencies beta coefficient indicates the positive direction of 0.310 pales HR competence is increased by one unit, and the other variables constant, the quality of financial reporting will increase by 0.310 units.

The results are consistent with Dervish and Desi Mahyani (2009), Muhammad Nur Nuryanto \& Nunuy AFIAH (2013), Y. Erlynda Kasim (2015) was the result of his research revealed simultaneously Human Resource Competency positive effect on the quality of financial reporting. The results of this study are also consistent with the Su-Chin Hsieh et al (2012) in his research that discusses the literature analysis review competence where the results show that the mapping of competencies is the process a person uses to identify and describe the competencies that are most important to success in the work situation or job roles, In the trend of human resource management at this time, the emphasis is more on mapping competencies which help in improving performance. Meanwhile, according to research Draganidis, F \& Mentzas, G (2006) 
Soderquist and Papalexandris (2010) states that there is a strong relationship between the individual and organizational competencies. It is mainly because the organization has the capability of the apparatus, and use of knowledge is the key to gain a sustainable competitive advantage.

\section{Influence of Leadership Style on the Quality of Financial Reports}

Among the three dimensions of leadership style, dimension style is a relationship-oriented leadership that has the lowest score compared to the actual dimensions of the existing categories in the category of "good" with an average score of 3,60 with a percentage amounted to $72,1 \%$.

In the dimension of relationshiporiented leadership style, which is the lowest value obtained at point statement to 5, Leaders need to seek the direction of the relationship employees to smooth reporting and preparation of financial statements. It shows that there is still an employee in the finance department who feel the relationship between employees in his office has not been good, so in the process of preparing the financial statements did not go well.

Based on the results of the first hypothesis testing showed that the leadership style of a positive and significant effect on the quality of financial reporting. T-count for leadership style variable of 2.345 higher than t-table 2.021 or when seen from the significant value is far below the $5 \%$ error rate of 0.024 produces Ho rejected, and $\mathrm{Ha}$ accepted means that the style of leadership significantly influence the quality of financial reporting. In addition, beta coefficient indicates the direction of positive leadership styles of 0.255 means that if the leadership style increased by one unit and the other variables constant, the quality of financial reporting will increase by 0.255 units.
The results are consistent with Adawi and Rwegasira (2011) says that the leadership experience, educational qualifications, and age of the leaders in the ability to lead an organization into one of the significant factors that increase organizational effectiveness. Also, according to Manz et al. (2008) and Trevin and Brown (2004) argue that the leadership style should be ethical, effective, and thriving in the long term. Leaders Must demonstrate the highest moral standards and ethical behavior in everyday conversation, actions, decisions, and behaviors so that other subordinates in an organization can keep up.

\section{Effect of Utilization of Information Technology on the Quality of Financial Reports}

Among the three dimensions in the use of IT, maintenance dimension is given a score which is the lowest compared to the dimensions that exist despite the fact that the category in the category of "good" with an average score of 3.5 with a percentage of 71 $\%$. In this maintenance dimensional lowest value obtained at point statement to 20 that is an update to the antivirus in institutions equipped with paid antivirus. This shows that respondents believe the security of data storage for all transactions and financial statements in data processing equipment (computer/laptop) must have antivirus software is kept updated and paid. Because if it is not updated anti-virus it is possible that transactions and financial statement data can be lost by a virus that attacks the data processing equipment.

Based on the results of the first hypothesis testing showed that IT utilization and significant positive effect on the quality of financial reporting. T-count for IT utilization variables for 8,922 greater than 2,021 t-table or when seen from the significant value is far below the $5 \%$ error 
rate of 0.000 produces Ho rejected, and $\mathrm{Ha}$ accepted means of IT utilization significantly influence the quality of financial reporting. In addition, the use of IT beta coefficient of 0.582 indicates a positive direction means that if the use of IT increases by one unit and the other variables constant, the quality of financial reporting will increase by 0.582 units.

The results are consistent with Alaves (2010) shown in the fact that many companies invest heavily in the development of information technology. Some fields in the company take advantage of information technology to solve the jobs related to accounting. Meanwhile, according to $\mathrm{M}$. Khrisna Moorthy, et al. (2012) suggest that by adopting the right technology and systems in the management of accounting, the company and the accountant can produce accurate reports.

Then Lim (2013) in his research stating that the use of information technology, many transactions are processed more easily so that the entity becomes more efficient operation, and utilization of information technology makes the flow of information to become more effective and efficient, thereby strengthening managerial decision making. The flow of data and information more effectively and efficiently through the use of information technology in the preparation and presentation of financial statements strengthen managerial decision making in their respective work units through the benefits of feedback, predictive benefit, timeliness, and completeness of the information provided in the financial statements. Then the use of information technology in the preparation and presentation of financial statements also affect the reliability of the data and information presented in the financial statements, for each transaction can be easier to be traced and verified the truth through the applications that are used in the preparation of financial statements.

\section{Effect of Internal Control of the Quality of Financial Reports}

Among the five dimensions in internal control, risk assessment is the dimension that has the lowest score compared to the existing dimension and into the category of "Good Enough" with average score of 3.4 with a percentage of $67 \%$, In the dimension of risk assessment is the lowest value obtained in the statement items 5 and 6 that the policies / guidelines for risk assessment and implementation and control / risk management plans. This shows that employees believe policies/guidelines for risk assessment and implementation are made regularly and documented as well as control/risk management plans should continue updated periodically according to changes in the needs or expectations of steak holder and carried automatic monitoring by the leadership of the organization, so that risk management can directly be known by the leaders

Based on the results of the first hypothesis testing showed that internal control and significant positive effect on the quality of financial reporting. T-count for internal control variables for 7,299 greater than 2,021 t-table or when seen from the significant value is far below the $5 \%$ error rate of 0.000 produces Ho rejected and $\mathrm{Ha}$ accepted means of internal control significant effect on the quality of financial reporting. Besides internal control beta coefficient of 0.356 indicates a positive direction means that if the internal control is increased by one unit and the other variables constant, the quality of financial reporting will increase by 0.356 units.

The results are consistent with Gramling et al. (2004) stated that based on reviews of previous surveys and 
experimental studies, argues that internal controls have the potential to affect the quality of corporate governance, financial reporting quality and performance of the company. Then, according to research GrasGil et al. (2012) found that companies with high-quality financial statements have better cooperation between internal and external auditors in the annual audit. Specifically, they found that the greater participation of internal audit in the review of the financial reporting process causes an increase in the quality of financial statements. Meanwhile, according to Setyawati Hari (2013) said that competence, leadership commitment to the organization and implementation of the internal control system simultaneously has a positive influence on the quality of financial reporting Especially in local government. It is in line with research Jessy L. Dimarcus Warongan, Gagaring Pagalung, Paul Uppun, and Abdul Hamid habbe (2014) stated that the existence of positive and significant influence on the competence of human resources to the quality of financial reporting through the effectiveness of internal control systems. On the other hand, found a significant mediating effect on the audit opinion on the quality of financial reporting through the effectiveness of the internal control system.

\section{Conclusion, Recommendations and Limitations}

\section{Conclusions and Recommendations}

Based on the research and hypothesis testing that has been done, then the results can be summarized as follows: Competence HR, Leadership Style, Utilization of IT and Internal Control either partially or simultaneously positively significantly have an impact on the quality of financial statements.
Based on the discussion and the above conclusions, the researchers gave suggestions to the Directorate General of Construction Ministry of Public Works and Public Housing is Chairman Agencies in order to give an opportunity to the employees, especially section of finance to participate in various training and technical assistance in the field of finance, both carried out by the institution or by other agencies. So that employees can improve their competence in financial management. Increasing human resource competencies in financial management financial statements will eat more quality, leadership institutions in order to provide direction and policy on relationships with employees for the smooth preparation of the financial statements. A good relationship and harmony among employees, both in financial and other fields will smooth process of preparation of financial statements and improve financial reporting quality, In the use of information technology is increasingly low overhead, it should be balanced with the provision of advice and adequate infrastructure in each unit work, so it needs the direction and development policy of the leadership to guarantee adequate maintenance and support necessary budget for each unit of work in seeking that the utilization of information technology can be utilized optimally, Head of Agencies in order to provide direction and policy in the development of policies / guidelines risk assessment and implementation are made regularly and documented as well as control/risk management plans should continue to update periodically according to changes in the needs or expectations do steak holder and automated monitoring by head of the institution, so that risk management can be known immediately by the leadership. By improving the implementation of internal control in all work units it will avoid fraud 
and errors and will give confidence to the financial statements.

For future studies should also use the method of interview or interviews in addition to the questionnaires to obtain more accurate data, the same study, for further research to try to repopulate, indicators, dimensions and methods of analysis differs from previous studies in order to see the comparison results of the analysis, can add a new variable / replace one variable to another variable that will broaden their horizons and knowledge for researchers and readers.

\section{Limitations study}

Some limitations in the research that could affect these results include 1) This conclusion applies only to the scope of the Directorate-General for Construction and Development not be generalized to other General Directorate within the Ministry of Public Works \& PERA. 2) The scope of this study is the perception so that the individual characteristics of respondents strongly influence the responses to questionnaires that will ultimately affect the study. 3. In this study, Variable Utilization of Information Technology and Internal Control does not have a value of variability that can not be used as a variable. 4. In this study, as respondents only on the scope of the intern in the Directorate General of Construction Ministry PUPR and does not involve external parties.

\section{References}

Adawi, M. and Rwegasira, K. (2011), "Corporate boards and voluntary implementation of best disclosure practices in emerging markets: evidence from the UAE listed companies in the middle east",
International Journal of Disclosure and Governance, Vol. 8, pp. 272-293.

Alaves, Mario do Ceu Gaspar. 2010. Information Technology Roles in Accounting and Finance, Vol. 1, No. 1, Juni 2010 2010-023X.

Bastian, Indra. 2006. Akuntansi Sektor Publik: Suatu Pengantar. Jakarta: Penerbit Erlangga.

Bambang Supomo dan Nur Indriantoro, 2002. Metodologi Penelitian Bisnis. Cetakan Kedua, Yogyakarta: Penerbit BFEE UGM

Boyatzis, Richard E, 2009. Competencies as a Behavioral Approach to Emotional Intelligence. Journal of Management Development, Vol, 28 Iss, 9. Pp. 749-770

Draganidis F., Mentzas G. (2006) "Competency based management a review of system and approaches". International Journal of Information Management and Computer Security, Vol 14, No. 1 2006, pp. 51-64

Erlynda Y. Kasim, 2015. Effect of Government Accountant Competency and Implementation of Internal Control to The Quality Of Government Financial Reporting. International Journal of Business, Economics and Law, Vol. 8, Issue 1 (Dec.) ISSN 2289-1552

Endang Setyaningdyah, Umar Nimran, Kertahadi., and Armanu Thoyib. 2013. The Effect of Human

Resource Competence, Organization Commitment, and Transactional Leadership on Work Disciline. Job Statisfaction and Employee's Performance Interdiciplinary Journal 
of Contemporary Research in Bussiness, Vo 5, No. 4

Gramling, et al, 2004. "The role of the internal audit function in corporate governance: a synthesis of the extant internal auditing literature and directions for future research". Managerial Auditing Journal, Vol. 27 No. 8, pp. 728-753.

Gras-Gil et al, 2012. "Internal audit and financial reporting in the Spanish banking industry". Managerial Auditing Journal, Vol. 27 No. 8, pp. 728-753

Hsieh, Su-chin (et.al.), 2012. Analysis on Literatur Review of Competency. International Review of Business and Economics. Vol.2 pp.25-50.

Indriasari, Desi dan Ertambang Nahartyo (2008), Pengaruh Kapasitas Sumber Daya Manusia, Pemanfaatan Teknologi Informasi, dan Pengendalian Intern Akuntansi Terhadap Nilai Informasi Pelaporan Keuangan Pemerintah Daerah, Simposium Nasional Akuntansi, XII, Pontianak.

International Public Sector Accounting Standards Board, 2003. Transition to the Accrual Basis of Accounting: Guidance for Public Sector Entities Third Edition, International Federation of Accountants, New York. (diakses dari www.ifac.org)

International Public Sector Accounting Standards Board, 2011. Transition to the Accrual Basis of Accounting: Guidance for Public Sector Entities Third Edition, International Federation of Accountants, New York. (diakses dari www.ifac.org)
Kementerian PU \& PERA, 2016. Laporan Keuangan Pemerintah Pusat (LKPP) (Audited) Tahun 2015. Kementerian PU \& PERA. Jakarta.

Lim, Francis Pol C. 2013. Impact of Information Technology on Accounting Art, Humanities, and Sociology, Vol. 3, No. 2, December (2013), pp. 107-129.

Manz, C. C., V. Anand, M. Joshi and K. P. Manz: 2008, "Emerging Paradoxes in Executive Leadership: A Theoretical Interpretation of the Tensions Between Corruption and Virtuous Values". The Leadership Quarterly 19, 385-392.

Mardiasmo.2005. Akuntansi Sektor Publik, Edisi 2. Yogyakarta: Andi Yogyakarta

Mega Meilistya. 2010. Kajian Terhadap Suspen dan Upaya Meningkatkan Keandalan Data Laporan Keuangan. Jakarta; Kementerian Keuangan.

Mulyani, Sri, Rohail Hasan and Fajar Anugrah. 2015. The critical success factor for the use of informastion system and its impact on the organization performance international Business Management 10 (4) : 553-560, 2016. ISSN: $1993-$ 5250, Medwell Journals, 2016. Melalui: docsdrive.com/pdf/medwelljournals/i bm/2016/552-560.pdf....,[24/06/16]

M. Krishna Moorthy, et all. 2012. Aplication of Informastion Technology in Management Accounting Decision Making, International Journal of academic Research in Business and 
Social Sciences, March 2012, Vol.2, No.3 ISSN: 2222-6990

Muhamad Nuryanto; Nunuy Nur Afiah. 2013. The impact of Apparatus financial Statemen Quality (Study on Local Government of Jakarta Province - Indonesia). World Review of Business Research, Vol 3. No.4. November 2013, 157 - 171

Naresh K. Malhotra.2010. Market Research: an Applied Orientation Sixth Edition Pearson Education.

Peraturan Pemerintah Nomor 24 Tahun 2005 Tentang Standar Akuntansi Pemerintahan. (www.google.com) [4/1/2011].

Peraturan Pemerintah Nomor 71 Tahun 2010 tentang Standar Akuntansi Pemerintahan. Jakarta.

Peraturan Pemerintah Nomor 60 tahun 2008 tentang Sistem Pengendalian Internal Pemerintah (SPIP). Jakarta.

Peraturan Menteri Keuangan Nomor 210/PMK.05/2013 tentang Pedoman Rekonsiliasi dalam Rangka Penyusunan Laporan Keuangan Lingkup Bendahara Umum Negara dan Kementerian Negara/Lembaga. Jakarta.

Undang-undang Republik Indonesia Nomor 17 Tahun 2003 tentang Keuangan Negara. Jakarta

Undang-undang Republik Indonesia Nomor 1 Tahun 2004 tentang Perbendaharaan Negara. Jakarta

Undang-undang Republik Indonesia Nomor 15 Tahun 2004 tentang Pemeriksaan Pengelolaan dan Tanggung Jawab Keuangan Negara. Jakarta.
Yukl, Gary, 1989, Leadeship in Organization, New Jersey: Prentice Hall, Inc.

Yukl, Gary, 2010, Kepemimpinan dalam Organisasi, Edisi Kelima. Jakarta: PT. Indeks. 